\title{
Impact of Prosecution Against Infringement Ticketing with Numbers Traffic Accidents in The Jurisdiction of Police Resort Semarang
}

\author{
Rudi Hendri Basuki ${ }^{1}$ and Umar Ma'ruf ${ }^{2}$
}

\begin{abstract}
This study aims to determine how is the implementation of the action by infringing traffic by a speeding ticket in the jurisdiction of Police in Semarang; How can the impact of infringing on a traffic enforcement with a ticket to the number of traffic accidents in the jurisdiction of Police in Semarang; and What constraints in action by infringing traffic by a speeding ticket in the jurisdiction of Semarang Police and how the solutions to overcome them.

The method used by the author in this study is juridical empirical or sociological jurisdiction. Specifications of research used is descriptive analytical

Based on research conducted can be concluded that 1) Implementation of Traffic Violations Enforcement accordance with Government Regulation on Infringement Ticketing Act No. 80 Of 2012 on Procedures for Vehicle Inspection and Enforcement Violations On the Road Traffic and Transportation Article 3, which reads Vehicle Inspection; 2) The results in January to September 2018 is known that the impact of a speeding ticket to a very significant definitely one transport accident means the higher the number the lower the accident rate speeding ticket, speeding ticket conversely the lower the number the higher the number of accidents; and 3) Constraints in the prosecution of traffic violations by a speeding ticket in the jurisdiction of Semarang Police isThe lack of legal awareness in the society, lack of ability by the Police Authority problematic legislation, the lack of infrastructure to support

Keywords: Impact; Infringement; Traffic; Infringement Ticketing; Accident.
\end{abstract}

\section{Introduction}

Traffic accidents are one of the major issues that must be faced by Indonesia today. Victims of traffic accidents from time to time showed a tendency to always go up. Similarly in the case-fatality traffic accidents seemed to increase. Each year, the death rate fromaccidentin Indonesia is the highest in the world. Amounts to 28-38 thousand per year in the counTrial lost their lives in traffic accidents. The United Nations (UN) highlighted the high number of deaths fromaccidentin Indonesia and the numbers as much as it is the highest in the world. Starting in 2014 until 2020,United Nations asks Indonesia to push that number up by half, ${ }^{3}$

By 2015, the number of fatalities has reached 30637 people, meaning that in every 1 hour there were about 3-4 people or every day about 84 people die from road traffic accidents. Nationally, $67 \%$ of victims of accidents are of childbearing age (22-50 years). This is of course a matter of concern and needs attention and serious treatment. Traffic accidents causing casualties. Both the human toll in this case may be in a state died, suffered serious injuries, minor injuries and may cause material loss and damage to the

\footnotetext{
${ }^{1}$ Student of Master of Law, Universitas Islam Sultan Agung Semarang and Members of the Indonesian National Police (Polri), email: rudihendribasuki@gmail.com

${ }^{2}$ Faculty of Law Universitas Islam Sultan Agung

3 https://www.liputan6.com/news/read/3167214/angka-kematian-akibat-kecelakaan-indonesia-tertinggi-didunia
} 
vehicles involved. The fatality rate is measured a traffic accident on the result of the accident there.

The government in this case the police who acted as public officials who must be able to make a public policy in providing services to the public. With the problem of the high number of traffic accidents there and the high fatality rate of any accident that occurs, the police should take a policy in carrying out the duties, functions and perananannya in providing services to the community as a representation or an extension of the government to overcome the existing problems of the, In addressing these issues the government has done preventive measures to reduce the high number of accidents among others is a violation enforcement system using a speeding ticket. ${ }^{4}$,

Law enforcement on traffic violations and road transport using the system ticketed has been carried out by the Semarang Police in handling traffic violations, and road transportation. The form of the law enforcement in the form of operations such as zebra operation, candle operations, traffic safety operation, the abiding operation and Ketupat operations.

Based on the description mentioned above, it can be formulated some problems in this study, are as follows: 1) How is the implementation of the action by infringing traffic by a speeding ticket in the jurisdiction of Semarang Police? 2) How can the impact of infringing on a traffic enforcement with a ticket to the number of traffic accidents in the jurisdiction of Semarang Police? 3) What constraint in repression by infringing traffic by a speeding ticket in the jurisdiction of Semarang Police and how solutions to overcome them?

\section{Research methods}

The method used by the author in this study is juridical empirical or sociological jurisdiction. In sociological juridical approach of law as law in action, described as an empirical social phenomena.

Specifications of research used is descriptive analytical research that describes the state of the subject or object in the research can be a person, institution, community and others which are now based on the facts that appear or what it is. Descriptive method is a method in researching the status of a group of people, an object, a set of conditions, a system of thought or a class of events in the present.

\section{Results And Discussion}

\subsection{Implementation Enforcement Traffic Violations By Infringement Ticketing In Semarang Police Jurisdiction}

Implementation of Traffic Violations Enforcement Infringement Ticketing accordance with Government Regulation No. 80 Of 2012 on Procedures for Vehicle Inspection and Enforcement Violations On the Road Traffic and Transportation Article 3, which reads on the Road Vehicle Inspection includes checking:

- Driver's License, Certificate of Vehicle Numbers, Letters Trial Vehicle, Vehicle registration number, or Identity TrialVehicle;

- Proof of passing test for compulsory vehicle test;

\footnotetext{
${ }^{4}$ Article 1 paragraph 4 Government Regulation No. 80 of 2012 on Procedures for Vehicle Inspection and Enforcement Violations Road Traffic and Road Transportation (PP 80/2012)
} 
- Physical vehicles;

- Haulage and / or means of transporting goods; and / or

- Transport operating licenses.

In the implementation penindakannya procedure consists of:

- Preparation

Before performing the action a violation of certain road traffic by using Form Infringement Ticketing preparations need to be done as follows: Infringement Ticketing blank that has been in seal / stamp of unity in accordance with needs including violations table and the money deposited; Ballpoint (black or blue); Blanko Infringement Ticketing upholstery tool set (Hard Board, Carton thick, slab zinc, etc.); Label evidence; By Stationary (place) prepare a notice board raid; In Hunting (Moving) Art 111 Criminal Procedure Code

- Procedures raid

- Warrant Tasks

- Events briefed leaders (APP)

- Division of tasks : Officers were reduced speed; Officer stopping traffic; Officers carrying out inspection; Officers who carry out repression with Infringement Ticketing; The officer in securing evidence; Officers who carry out security locations

- Implementation raid

After everything needed in order violation enforcement of certain road traffic using Form speeding ticket that has been prepared, the action can be done directly on the spot. If it finds a violation with the stages of the following activities:

Preparation Phase I write in Blanko Infringement Ticketing

Phase II Writing diblangko Infringement Ticketing

Phase III Signing defendant on Form Infringement Ticketing

Phase IV Delivery Infringement Ticketing To Offenders.

Phase V Receiving the Courier / Foreclosure defendant

Phase VI Return of Goods Forwarding To Defendant

Phase VII Return to Unit Unit Investigator Infringement Ticketing Blank Time Sheet, Receipt / tuber and Goods Forwarding / Foreclosure

\subsection{Impact prosecution traffic violation with a ticket to the number of traffic accidents in the jurisdiction of Semarang Police}

Data from Semarang Police, during the month of September 2017 until the month of Setember 2018 in Semarang Regency has happened 619 traffic accident scene. Of the events that much, 166 fatalities. While the victims who suffered severe injuries to 3 people and 510 other people suffered minor injuries.

Traffic Data In September 2017 - September 2018 Of Semarang Police

\begin{tabular}{ccccccc}
\hline \multirow{2}{*}{ No } & \multirow{2}{*}{ Month } & Number of & \multicolumn{3}{c}{ Victim } & \multirow{2}{*}{ Material losses } \\
\cline { 4 - 6 } & & events & MD & LB & LR & \\
\hline 1 & Sep-17 & 46 & 9 & 0 & 37 & Rp. 24.75 million \\
\hline 2 & Okt-17 & 84 & 19 & 0 & 65 & Rp. 30.25 million \\
\hline
\end{tabular}




\begin{tabular}{clccccc}
\hline 3 & Nov-17 & 52 & 12 & 1 & 39 & Rp. 25.3 million \\
\hline 4 & Des-17 & 43 & 11 & 0 & 32 & Rp. 19.65 million \\
\hline 5 & Jan-18 & 42 & 10 & 1 & 31 & Rp. 27.35 million \\
\hline 6 & Feb-18 & 43 & 13 & 0 & 30 & Rp. 11.75 million \\
\hline 7 & Mar-18 & 56 & 15 & 0 & 41 & Rp. 18.6 million \\
\hline 8 & Apr-18 & 47 & 18 & 0 & 29 & Rp. 14,500,000 \\
\hline 9 & Mei-18 & 45 & 11 & 0 & 34 & Rp. 13.95 million \\
\hline 10 & Jun-18 & 66 & 7 & 1 & 58 & Rp. 19.25 million \\
\hline 11 & Jul-18 & 47 & 12 & 0 & 35 & Rp. $12,000,000$ \\
\hline 12 & Aug-18 & 48 & 7 & 0 & 41 & Rp. 12.2 million \\
\hline 13 & Sep-18 & 60 & $\mathbf{2 2}$ & 0 & 38 & Rp. 23.15 million \\
\hline & TOTAL & $\mathbf{6 1 9}$ & $\mathbf{1 6 6}$ & $\mathbf{3}$ & $\mathbf{5 1 0}$ & Rp. 252.7 million \\
\hline
\end{tabular}

In order to reduce the number of traffic accidents on the highway, Semarang Police have conducted raids sanction obtained a speeding ticket on the way following data:

Infringement Ticketing Data Polres Semarang Of 2018

\begin{tabular}{|c|c|c|c|c|}
\hline \multirow{2}{*}{ No } & \multirow{2}{*}{ Month } & \multicolumn{2}{|c|}{ Types of infringement } & \multirow{2}{*}{$\begin{array}{l}\text { Number of } \\
\text { violations }\end{array}$} \\
\hline & & Ticketed & Strikes & \\
\hline 1 & January & 5685 & 853 & 6,538 \\
\hline 2 & February & 5421 & 1,355 & 6,776 \\
\hline 3 & March & 5,325 & 799 & 6124 \\
\hline 4 & April & 6168 & 925 & 7093 \\
\hline 5 & May & 4,252 & 637 & 4889 \\
\hline 6 & June & 196 & 20 & 216 \\
\hline 7 & July & 2,115 & 317 & 2,432 \\
\hline \multirow[t]{2}{*}{8} & August & 5656 & 848 & 6504 \\
\hline & TOTAL & 34818 & 5754 & 40572 \\
\hline
\end{tabular}

From these data revealed that in January 2018, accidents do occur 42 times as much as 5,685 times ticketed prosecution; in February the number of accidents 43 times do action as much as 5,421 times a speeding ticket; in March occurred 56 accidents do as much as 5,325 times ticketed prosecution; in April occurred 47 accidents do as much as 6168 times ticketed prosecution; in May occurred 45 accidents do as much as 4,252 times ticketed prosecution; in June occurred 66 accidents do action ticketed by 196 times; in July occurred 47 accidents do as much as 2,115 times ticketed prosecution; in August occurred 48 accidents do as much as 5656 times ticketed prosecution.

\subsection{Obstacles in the prosecution of traffic violations by a speeding ticket in the} Semarang Police Jurisdiction

- Law Enforcement

- Application of the law as stated in Act No. 22 of 2009 as well as government regulations are not implemented properly, such as the application of the articles penalty of Article 273 to article 317 and clauses governing the Education driver as set out in Article 78 to Article 79 in conjunction with Article 87 until the article 89. 
- Sentencing by judges against violators of traffic still refer to table a ticket (deal Courts, the Prosecutor and the Police) do not heed the threat of crime listed in the regulations stipulated in the articles listed in the Act No. 22 of 2009 with nominal fines Sangai relatively mild so that convictions do not provide a deterrent effect for offenders convicted.

- Consistency in the implementation of law enforcement has not been projected in an effort to increase traffic safety and legal compliance even though society has no concept of repression by the pattern of Potential Point Target System (SPPT) and regional implementation of traffic rules (KTL).

- Handling raids on four or more wheels require stopping area is quite wide, so the attendant difficulty finding the location of the raid for 4-wheel vehicles or more.

- E-ticket payment system via BRI outside the judicial process against traffic violations, to the amount of the fine was too high (maximum penalty) according to Act 22 of 2009.

- The lack of a means of supporting the speed in handling the scene of traffic accidents such as winches, cranes and other heavy equipment.

- Law Enforcement Attitude

a) Lack of moral ethics and professionalism as law enforcement officers as well as the arrogance that is inherent in carrying out law enforcement duties, b) The number of irregularities committed by way beyond the limits of authority, extortion, violent and do not reflect as a figure of protector and servant of the people c) Lack of coordination between law enforcement agencies both fellow law enforcement officers on the street as well as the elements of the Criminal Justice System (CJS). d) Implementation of law enforcement by civil servants investigator (investigators) Department of Transportation / LLAJR for misconduct in accordance with the authority is not exercised in accordance with existing regulations.

- Cultural Factors,

- Mental; Persistent Mental and behavior of road users is one of the main factors that influence on the traffic situation.

- knowledge: Every road user shall understand each rule that has been formally standardized in the form of the Act, a regulation, government regulations, legislation and other rules so that there is a perception in the pattern of action and mindset to interact on the highway.

- Skills; vehicle control skills are an absolute necessity for the sake of security, safety, traffic order and Kelancaraan good for the driver / rider of the vehicle and other road users.

- Infrastructures Factors

Means and inadequate road infrastructure with the number of vehicles that operate on the highway that does not grow will affect the smoothness and order traffic on the highway. ${ }^{5}$

\section{Closing}

\subsection{Conclusion:}

\footnotetext{
${ }^{5}$ Tjahyono, 2008, Rancangan Buku Pengantar Analisis Dan Prevensi Kecelakaan Lalu Lintas Jalan, Laboratorium Transportasi Departemen Teknil Sipil Depok, FT. UI. p. 11
} 
- Implementation of Traffic Violations Enforcement Infringement Ticketing accordance with Government Regulation No. 80 Of 2012 on Procedures for Vehicle Inspection and Enforcement Violations On the Road Traffic and Transportation Article 3, which reads Vehicle Inspection

- The results of the study in January to September 2018 is known that the impact of a speeding ticket to a very significant definitely one transport accident means the higher the number the lower the accident rate speeding ticket, speeding ticket conversely the lower the number the higher the number of accidents.

- Obstacles in the prosecution of traffic violations by a speeding ticket in the jurisdiction of Semarang Police is the lack of legal awareness in the society, lack of ability by the Police Authority problematic legislation, the lack of infrastructure to support.

\subsection{Suggestion :}

- In addressing traffic accident, traffic police have to include a complete infrastructure to accelerate the handling of the accident.

- It takes the participation of other agencies in disseminating programs of the police to prevent traffic accidents.

- The policies that have been taken should be implemented in a sustainable manner so that not only a momentary program but it can be a long-term program so that the objectives expected to overcome the existing problems can be actually achieved.

\section{Bibliography}

\section{Books:}

[1] H.S Djajoesman.,1976. Polisi dan Lalu Lintas, Dinas Hukum Polri, Jakarta.

[2] M. Karjadi,SH, Kejahatan Pelanggaran Dan Kecelakaan Lalu Lintas Jalan, Politeia, Bogor.

[3] Mohammad Nazir, 1988, Metode penelitian. Jakarta: Ghalia Indonesia

[4] Prof. Dr. Satjipto Raharjo, SH, Penegakan Hukum, Genta Publishing.

[5] Sugiono, 2005, Metode Penelitian Administrasi, Alpabeta, Bandung,

[6] Tjahyono, 2008, Rancangan Buku Pengantar Analisis Dan Prevensi Kecelakaan Lalu Lintas Jalan, Laboratorium Transportasi Departemen Teknil Sipil Depok, , FT. UI.

[7] Wirjono Projodikoro, 2003, Hukum Asuransi di Indonesia, Intermasa, Jakarta.

\section{Legislation:}

[1] Act No. 22 Of 2009 on Traffic and Road Transportation

[2] Government Regulation No. 80 Of 2012 on Procedures for Vehicle Inspection and Enforcement Violations Road Traffic and Road Transportation

\section{Website:}

[1] http://repository.unissula.ac.id/6916/5/BAB\%20I_1.pdf

[2] https://www.liputan6.com/news/read/3167214/angka-kematian-akibat-kecelakaan-indonesia-tertinggi-di-dunia 